\title{
Preface for Thematic Section: Sustainable Iron and Steelmaking
}

\author{
II Sohn ${ }^{1} \cdot$ Shigeru Ueda ${ }^{2}$
}

Published online: 18 June 2019

(c) The Minerals, Metals \& Materials Society 2019

Technology according to the Cambridge dictionary is defined as 'the study and knowledge of the practical, especially industrial, use of scientific discoveries' [1]. In terms of the energy used in 2018, the industrial sector used approximately $55 \%$ of the global energy, and the basic metals industry accounted for $12 \%$, which indicates a great need for the metals industry to minimize the usage and wastes of this valuable entity [2]. With the global environmental, economi$\mathrm{cal}$, and resourcing issues facing the metals and materials community, this definition of technology and its implementation requires a prerequisite of the technology to be sustainable for the industry. According to recent estimates [3], more than 30 billion tons of fossil-fuel-related $\mathrm{CO}_{2}$ were emitted in 2018 resulting in the highest level of $\mathrm{CO}_{2}$ concentrations in the atmosphere to date. Slags that are produced from the iron and steelmaking industry amount to more than $400 \mathrm{MT} /$ annum, and costs have significantly risen for treatment and utilization of a few of the steelmaking slags $[4,5]$. In the nonferrous aluminum smelting industry, more than $400 \mathrm{KT} /$ annum of the spent pot lining and other process wastes are unavoidable, and recycling of these materials has become an essential condition for continued operations [6]. These critical issues along with diminishing high-quality materials reserves have made it a priority to ensure sustainable technology development in the metals and materials industry.

With the above facts in mind, this thematic section on sustainable iron and steelmaking aims to provide an overview of the sustainability issues specific to the steel industry that is of interest to academics and industry professionals alike.
In this collection of articles, recent progress on steelmaking process coproducts, fundamentals in the selective removal of high-value-added nonferrous elements, and future ironmaking technology progresses are discussed.

These articles contain not only fundamentals of thermodynamics and kinetics, but also industrial-scale applications of reutilization, which should provide insights into the future sustainability of the iron and steelmaking industry.

\section{References}

1. Cambridge Dictionary https://dictionary.cambridge.org/dictionary /english/technology. Accessed 8 May 82019

2. U.S. Energy Information Administration. https://www.eia.gov/ todayinenergy/detail.php?id=38392. Accessed 8 May 82019

3. Harvey $\mathrm{C}$ (2018) $\mathrm{CO}_{2}$ emissions reached an all-time high in 2018 , E\&E News, Scientific American. https://www.scientificamerican. com/article/co2-emissions-reached-an-all-time-high-in-2018/. Accessed 8 May 82019

4. World Steel Association (2019) Fact sheet-Steel industry coproducts. https://www.worldsteel.org/en/dam/jcr:1b916a6d-06fd4e84-b35d-c1d911d18df4/Fact_By-products_2018.pdf. Accessed 8 May 82019

5. Wang Z, Sohn I (2019) A review on reclamation and reutilization of ironmaking and steelmaking slags. J. Sustain Metall 5:127-140

6. https://primary.world-aluminium.org/aluminium-facts/emissionswaste/. Accessed 8 May 82019

Publisher's Note Springer Nature remains neutral with regard to jurisdictional claims in published maps and institutional affiliations.

The contributing editor for this article was S. Kitamura.

Il Sohn

ilsohn@yonsei.ac.kr

1 Materials Science and Engineering, Yonsei University, Seoul 120-749, South Korea

2 Institute of Multidisciplinary Research for Advanced Materials, Tohoku University, Sendai 980-8577, Japan 